\title{
Testing Self-Determination Theory in Conflict-Affected Areas: A Case Study of Yemeni EFL Students
}

\author{
Jamal Kaid Mohammed Ali ${ }^{1}$ \\ ${ }^{1}$ English Department, College of Arts, University of Bisha, Bisha, Saudi Arabia \\ Correspondence: Jamal Kaid Mohammed Ali, English Department, College of Arts, University of Bisha, Bisha, \\ Saudi Arabia. E-mail: jamalalhomaidi@gmail.com
}

Received: June 20, 2019 Accepted: July 9, 2019 Online Published: July 17, 2019

doi:10.5539/ijel.v9n4p366 URL: https://doi.org/10.5539/ijel.v9n4p366

\begin{abstract}
This study investigates the impact of Yemeni conflict on EFL students' motivation from the new conceptualization of Self-Determination Theory. It particularly explores whether EFL students are more influenced by either autonomous or controlled motivation. Data were collected through the use of a questionnaire and interviews from English Department, College of Education, Zabid, Yemen. The Questionnaire was distributed to 60 male and female Yemeni EFL students. Interviews were conducted with five EFL teachers from the same department. The results of the data showed that conflict has negatively affected Yemeni EFL students. Findings also indicated that EFL students tend to be more controlled than to be autonomously motivated and that the students at levels 1 and 2 are more autonomously motivated as compared to those at levels 3 and 4 . This showed that level 3 and 4 students have lost some of their idealism due to the seriously deteriorated situation in all the various aspects of life.
\end{abstract}

Keywords: autonomous motivation, conflict-affected areas, controlled motivation, Self-Determination Theory, Yemeni EFL students

\section{Introduction}

Yemen has faced political instability since 2004. Six civil wars have plagued Yemen between 2004 and 2010. Then, the so-called Arab Spring in 2011 led to another disastrous civil war in 2014. This political instability has led to the eruption of violence, restlessness, destruction and closure of most of the public buildings, including public schools and universities followed by the non-payment of salaries of almost all the public employees, including EFL teachers. Teachers who are working in some cities and towns, particularly those in Zabid (controlled by Houthis), where this study has been conducted, have not received their salaries since August 2016. There is no public electricity since the beginning of the war. People are managing with private electricity generators or using solar energy panels. Inflation is high and there are often severe shortages of gas and other fuels. Schools and universities are used as shelters for the Houthi fighters and sometimes as military barracks. The wood of the chairs has been cut into pieces to provide fuel for cooking. Finally, the indelible suffering of Yemenis has affected the students' motivation to study English.

The present study was an attempt to shed light on the effect of conflict on Yemeni EFL students' motivation and to find out what motivates them to keep learning despite the current conflict. This study explores Yemeni EFL students' motivation from the new vision of Self-Determination Theory (SDT) perspective which classifies motivation as autonomous versus controlled and not as intrinsic versus extrinsic. SDT currently differentiates between the types of motivation along a continuum from controlled to autonomous (Deci \& Ryan, 2012, p. 8; Ryan \& Deci, 2017, p. 14). The new conceptualization of SDT is presented in Table 1 below. 
Table 1. A continuum of motivation: past and present

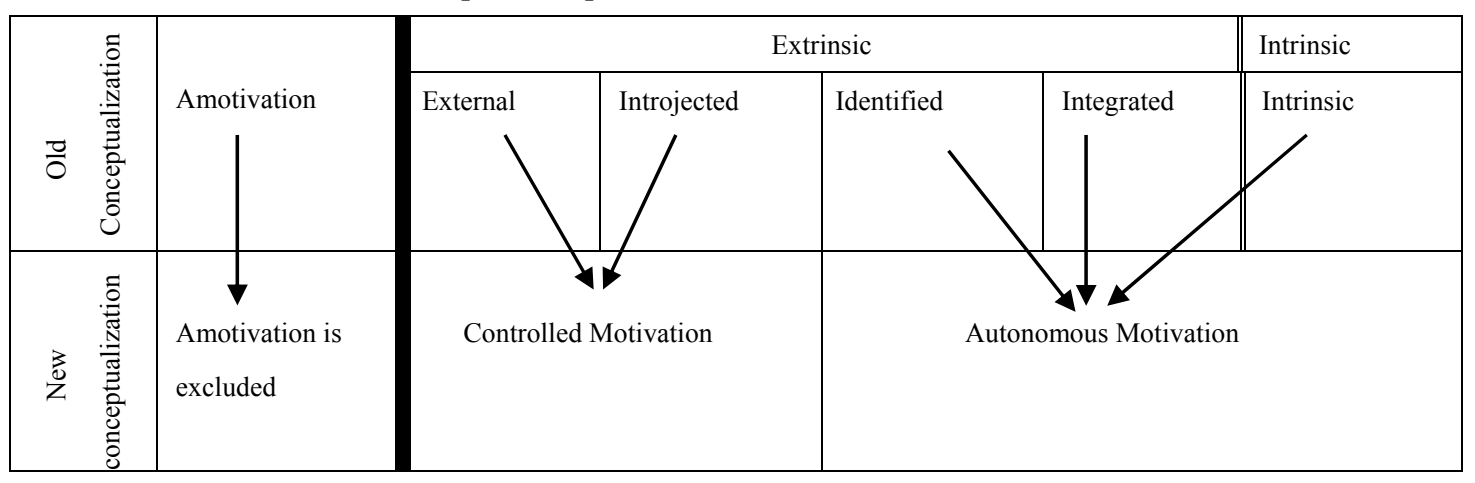

Note. The old conceptualization was adapted from Deci and Ryan, 2002.

Table 1 shows that amotivation is excluded in the new conceptualization of SDT. It shows that controlled motivation is different from the continuum of extrinsic motivation as controlled motivation encompasses only two regulations of the extrinsic motivation (external and introjected). It also shows that autonomous motivation is not the same as intrinsic motivation because autonomous motivation encompasses two regulations of the extrinsic motivation (identified and integrated) in addition to intrinsic regulation. Thus, extrinsic motivation (identified and integrated) becomes a form of autonomous motivation (Deci \& Ryan, 2012; Ryan \& Deci, 2017, p. 14).

The current study seeks to answer the following research questions:

1) What are the effects of conflict on Yemeni EFL students?

2) Are Yemeni EFL students autonomous or controlled motivated?

3) Is there a significant gender difference in motivation?

4) What could motivate Yemeni EFL students in the current situation?

\section{Review of Literature}

\subsection{Self-Determination Theory (SDT)}

Deci and Ryan (1985), based on their empirical research, concluded that when people learn because of pleasure and enjoyment, they are intrinsically motivated. Deci, Connell and Ryan (1989) asserted that a self-determined student is the one who can initiate and regulate his/her actions. In a later study, Ryan and Deci (2000) discussed four types of extrinsic motivation, which ranged from the least autonomous to the most autonomous and that there is only one type of intrinsic motivation, which currently is termed autonomous motivation. Deci and Ryan classified the four types of extrinsic motivation as (a) external regulation, (b) introjected regulation, (c) identified regulation and (d) integrated regulation. External regulation occurs when a student feels pressure from the outside to study, which enables them to receive external rewards and avoid punishments or constraints. In the case of introjected regulation, Deci and Ryan concluded that a student feels a need for studying but does not fully accept that need as coming from within himself/herself. The lack of acceptance results from a desire to avoid guilt or shame, or to achieve self-esteem even though the student may not value the action. Further, identified regulation reflects an inner value of student behaviour. Students engage in behaviour because they consider it important. Integrated regulation is, therefore, the most autonomous regulation of extrinsic motivation. It refers to student behaviour as the result of the assimilation of identified regulation into student values (Chanal \& Guay, 2015; Chang, 2017; Dillon \& Stolk, 2012; Feri, Soemantri, \& Jusuf, 2016; Ryan \& Deci, 2000; Stolk et al., 2018).

Deci and Ryan (2012, pp. 8-9) found that "With this new conceptualization, the most salient and important distinction within SDT" is neither "intrinsic versus extrinsic motivation" nor "internal versus external to the person", but is rather "autonomous versus controlled motivation". Hence, SDT theory is a distinction between two types of motivation: autonomous motivation and controlled motivation. Ryan $(2009$, p. 2$)$ observed that "SDT research shows that the more autonomous the person's motivation, the greater their persistence, performance and well-being at an activity or within a domain." Ryan and Deci (2019, p. 120) concluded that introjected controlled motivation can be fragile and presents risks for well-being. They also concluded that external controlled motivation is difficult to sustain and "...has, therefore, poor maintenance and transfer qualities." 


\subsection{Motivation Studies in Yemen}

Al-Sohbani (1997) studied motivation of Yemeni Secondary School EFL students. He distributed a questionnaire to 496 students from five secondary schools and found that most of the students were highly motivated to study the English language. Al-Quyadi (2000) conducted a study on Yemeni EFL students in seven colleges at Sana'a University to investigate the psycho-sociological variables in learning English. The status of integrative and instrumental motivation in Yemeni EFL students was probed. He administered a questionnaire to $518 \mathrm{EFL}$ students whose major was English and found that EFL Yemeni students had a high level of integrative and instrumental motivation to learn English. Nine years later, Al-Tamimi and Shuib (2009) administered a questionnaire and interviewed Yemeni EFL students of Petroleum Engineering to identify their motivation towards learning the English language. The study was a probe of the levels of integrative and instrumental motivation. They also administered a questionnaire and interviewed 81 students at Hadhramout University of Sciences and Technology. Findings were that students manifest more instrumental than integrative motivation.

Al-Tamimi and Shuib's (2009) study was conducted using non-English major students who usually study English as a requirement, which could be a reason why they were instrumentally motivated to learn English. However, Al-Quyadi's study (2000) was conducted using English major students who decided to study English. They found the students had an integrative and instrumental motivation to learn English. Attamimi and Abdul Rahim (2011) studied the relationship between motivation to learn English and the socio-economic factors of Yemeni students. They administered a questionnaire and conducted semi-structured interviews with 142 Yemeni EFL students who were majoring in English at the Colleges of Arts and Education, Hadramout University of Science and Technology. They found that these students were highly motivated to learn English and they showed a more integrative motivation towards studying English.

Most of Yemeni EFL students' motivation was based on integrative and instrumental motivation (Al-Quyadi, 2000; Al-Sohbani, 1997; Al-Tamimi \& Shuib, 2009; Attamimi \& Abdul Rahim, 2011). Recent studies such as Al-Kadasi (2016), Al-Sohbani (2015), and Saeed (2015) confirmed the earlier findings. There was only one study that studied intrinsic motivation and the continuum of extrinsic motivation to learn English (Boset et al., 2017). Boset explored the relationship between Yemeni EFL teacher competence and their motivation to teach English. Boset did not study student motivation to learn English, but rather teachers' motivation to teach English.

\subsection{Self-Determination Theory in Conflict-Affected Areas}

The present study is the first research to investigate SDT in conflict-affected areas and the first study to investigate the effects of conflict on EFL students. Rajab (2018, pp. 67-83) investigated the effectiveness and potential benefits of e-learning for computer students in war zones. Rajab concluded that e-learning offers safe learning in that the desired learning objectives and outcomes could be achieved via online learning in conflict-affected areas. Badrasawi et al. (2018, p. 589) recommended specific strategies to provide and improve education in conflict-affected areas. They state that the literature suggested the following as examples:

... ending the conflict and removing the reasons for the conflict, maintaining the spirit of hope and determination among children, understanding the context, obtaining accurate data and establishing a consultative process, offering high-quality programs, training teachers and creating secure premises, offering a holistic approach to learning and applying community-based solutions etc. (p. 589).

Burns and Lawrie (2015) studied teacher learning and professional development within fragile situations and confirmed their belief that a teacher was the most important element to achieve the objectives and outcomes of education.

Finally, the present study of SDT employed its most recent conceptualization, which classifies motivation as either autonomous or controlled. As such, the present study is the first research that tests SDT's new conceptualization (autonomous and controlled motivation) in conflict-affected areas. It is also believed to be the first study to investigate the Yemeni or Arab EFL student motivation in terms of autonomous and controlled motivation from SDT perspective.

\section{Methods}

This section presents the research methodology that was followed in the current study.

\subsection{Instruments}

In July 2017, a special attempt was made to contact Professor Edward L. Deci to consult him about a questionnaire designed to study EFL student motivation in conflict-affected areas. Deci suggested an alternative 
questionnaire and observed, "I think the best questionnaire for motivation (autonomous and controlled) would be the Self-Regulation Learning Questionnaire.” Professor Richard M. Ryan, in a correspondence email in 2017, referred this researcher to Oga-Baldwin, who approved using the proposed questionnaire for Yemeni EFL students as well as the proposed interview protocol for Yemeni EFL teachers.

This study, thus, was implemented with both quantitative and qualitative methods to investigate the levels of autonomous and controlled motivation. The Learning Self-Regulation Questionnaire (SRQ-L) was distributed to students and the teachers were interviewed about the effects of the war on EFL student motivation. The questionnaire was comprised of two sections. The first section was intended to determine the respondents' gender and their study level at the university, while the second was the Learning Self-Regulation Questionnaire (SRQ-L). The latter was adapted from Ryan and Connell's (1989) questionnaire, which was designed for school students .The adapted version was designed for university students (Williams \& Deci, 1996) and consisted of 14 items. Seven items $(1,3,6,9,11,13,14)$ were coded on autonomous motivation (identified regulation, integrated regulation and intrinsic regulation). A sample item of autonomous motivation was: "I will continue to improve my English language because it is interesting to learn English language to know how it work." The other seven items $(2,4,5,7,8,10,12)$ were coded on controlled motivation (external regulation and introjected regulation). A sample item for controlled motivation was: "I will continue to improve my English language because I would feel proud if I continue to improve my English language skills."

Chang (2017, p. 499) stated that "As one's autonomy development can be explained by one's self-regulatory behaviours, a student's development of autonomy can be investigated through how he/she evaluates his/her participation in a learning task." The researcher, therefore, used the Learning Self-Regulation Questionnaire (SRQ-L), which asks the students why they (a) participate in the classroom, (b) follow their instructor's suggestions and (c) continue to improve their English language. Each question provided reasons that code as either autonomous or controlled (Black \& Deci, 2000).

The researcher translated the questionnaire into Arabic, which was then reviewed by an expert translator from the Department of English. The students answered using a 5-point Likert-scale from strongly agree to strongly disagree. The questionnaire is available online in a Google Docs format. Students were asked to respond online. The interviews, which were conducted with five teachers, consisted of two unstructured questions. The questions were designed to explore the effect of the Yemeni conflict on the EFL students and how to promote their autonomous motivation during the current situation in Yemen. The questionnaire was sent to Dr Nabil Awadh Farae, an Associate Professor at the same department and through him the questionnaire and the interview reached respondents.

\subsection{The Sample}

In order to study the Yemeni EFL students' motivation towards learning English, 32 female and 28 male Yemeni students studying English in the Department of English, College of Education, Zabid, Hodiedah University were selected to participate in this research. Almost all the participants are between the age of 19-24, undergraduates and native speakers of Arabic. Five Yemeni EFL teachers who currently live in Yemen have also been interviewed. The participants are all Yemenis and they, like all other Yemenis, have been suffering as a result of the constant state of conflict in Yemen. Their town has been controlled by the Houthis since 2014. The war continues in Zabid and teachers have not received their salaries since 2016 but continue to teach without being paid. The students' guardians, too, face the same problem as the situation in Yemen is unstable and, therefore, the students find it difficult to study properly.

\subsection{Reliability and Validity}

The questionnaire was developed by Ryan and Connel in 1989 and it was adapted by William and Deci in 1996. Professor Edward L. Deci suggested the questionnaire and the interview was approved by Oga-Baldwin who was referred by Professor Richard M. Ryan. Cronbach's alpha for the autonomous sub-scale was .738 and for the Controlled sub-scale was .765. These figures both exceed the minimally acceptable Cronbach alpha of .70.

\section{Results and Discussion}

\subsection{Preliminary Screening Procedures}

\subsubsection{Checking for Normality}

A variable is normally distributed if its skewness Index (skewness statistic/standard error) is less than three and its kurtosis Index (kurtosis/standard error) is less than 10 (Kline, 2011). The three dependent variables were normally distributed in Table 2 below. 
Table 2. Skewness and Kurtosis for the dependent variables $(\mathrm{N}=60)$

\begin{tabular}{lllll}
\hline Variable & Skewness & Skewness Index & Kurtosis & Kurtosis Index \\
\hline Autonomous Motivation & -1.41 & 2.98 & 2.50 & 5.28 \\
Controlled Motivation & 0.14 & 0.22 & -0.58 & -0.93 \\
Relative Autonomy Index & 1.38 & -.93 & 1.38 & 1.91 \\
\hline
\end{tabular}

\subsubsection{Screening for Outliers}

To detect univariate outliers, the variables were standardized; cases whose standardized values exceeded the absolute value of 3.29 are deemed to be outliers (Tabachnick \& Fidell, 2007). One of the cases met this criterion. A male, level 3 student had a standardized autonomous score of -3.37 . Because the other two measures for this student were not outliers, there is no reason to believe that this was an error. The analyses were run with, and without, this outlier and the conclusions did not change. The outlier was retained in the data set.

\subsection{Descriptive Statistics}

\subsubsection{Description of the Sample}

Nine of the respondents were at Education level $1(15 \%)$ and another nine were at education level $2(15 \%)$. Seventeen respondents were at education level $3(28.3 \%)$ and 25 were at education level 4 (41.7\%). Because of this imbalance, the t-tests of the independent variables divided the respondents into levels 1,2 and 3 versus level 4. The sample was close to balance with regard to gender: 32 (53.3\%) female and 28 (46.7\%) male.

Table 3. Frequencies and percentages for the demographic variables $(\mathrm{N}=60)$

\begin{tabular}{lll}
\hline Variable & $\mathrm{N}$ & $\%$ \\
\hline Education Level & & \\
& & \\
1 & 9 & 15 \\
2 & 9 & 15 \\
3 & 17 & 28.3 \\
4 & 25 & 41.7 \\
Gender & & \\
Female & 32 & 53.4 \\
Male & 28 & 46.7 \\
\hline
\end{tabular}

\subsubsection{Descriptions of the Dependent Variables}

The descriptive statistics for the main variables are shown in Table 3. Cronbach's alpha for the autonomous subscale was .738. A scale is considered acceptable if the Cronbach's alpha is .70 or higher. Cronbach's alpha for the controlled subscale was .765 . Both scales achieved acceptable alphas. Autonomous motivation scores ranged from 17 to 34 with a mean of $29.4(\mathrm{SD}=3.67)$. Controlled motivation scores ranged from 14 to 35 with a mean of $24.0(\mathrm{SD}=4.80)$. The Relative Autonomy Index was calculated as the difference between the autonomous and controlled motivation scores. Relative Autonomy Index scores ranged from -13 to 15 with a mean of 5.33 ( $\mathrm{SD}=$ 5.6). Autonomous and controlled motivation are not significantly correlated $(\mathrm{r}=.14, \mathrm{n}=60)$. Note that the items were all scored as " $1=$ Strongly Agree" to " $5=$ Strongly Disagree." As a result, the lower the score, the higher the level of motivation. A positive score on the Relative Autonomy Index indicates that respondents are more controlled motivated than autonomously motivated.

Table 4. Descriptive statistics for the study variables $(N=60)$

\begin{tabular}{llllll}
\hline Variable & alpha & Item n & Range & Mean & SD \\
\hline Autonomous Motivation & .738 & 7 & $17-34$ & 29.4 & 3.67 \\
Controlled Motivation & .765 & 7 & $14-35$ & 24.0 & 4.80 \\
Relative Autonomy Index & & & $13-15$ & 5.33 & 5.60 \\
\hline
\end{tabular}

\subsection{Comparison of Autonomous and Controlled Motivation Across all Respondents}

As seen in Table 4, across all respondents, the autonomous motivation score is, on an average, higher than the controlled motivation score, indicating that respondents tend to be more controlled motivated than autonomous 
motivated $(t=7.37, n=60, p<.001)$. In examining the data, it was noted that only 7 of the 60 respondents were more autonomous motivated than controlled motivated.

Table 5. Comparison of autonomous and controlled motivation across all respondents $(\mathrm{N}=60)$

\begin{tabular}{llllll}
\hline Variable & $\mathrm{N}$ & Mean & Variance & $\mathrm{T}$ & $\mathrm{P}(2$-tail $)$ \\
\hline Autonomous Motivation & 60 & 29.4 & 13.5 & 7.37 & $<.001$ \\
Controlled Motivation & 60 & 24.0 & 23.0 & & \\
\hline
\end{tabular}

Note. Paired t-test.

\subsection{Differences Between Male and Female Respondents on the Study Variables}

As shown in Table 6, there were no significant differences between male and female respondents on any of the three motivation measures.

Table 6. Differences between male and female respondents on the main study variables $(\mathrm{N}=60)$

\begin{tabular}{|c|c|c|c|c|c|c|}
\hline Variable & Gender & $\mathrm{N}$ & Mean & Variance & $\mathrm{t}$ & $\mathrm{P}$ (2-tail) \\
\hline \multirow[t]{2}{*}{ Autonomous Motivation } & Female & 32 & 3.12 & 12.1 & -.09 & NS \\
\hline & Male & 28 & 6.91 & 15.6 & & \\
\hline \multirow[t]{2}{*}{ Controlled Motivation } & Female & 32 & 23.9 & 20.7 & -.24 & NS \\
\hline & Male & 28 & 24.2 & 26.5 & & \\
\hline \multirow[t]{2}{*}{ Relative Autonomy Index } & Female & 32 & -5.44 & 31.0 & & \\
\hline & Male & 28 & -5.21 & 33.0 & .15 & NS \\
\hline
\end{tabular}

Note. 2 -sample t-tests, assuming equal variances.

\subsection{Differences Between Respondents at Education Levels 1-3 Vs 4 on the Study Variables}

As shown in Table 7, there is no significant difference between respondents at levels 1-3 and respondents at level 4 on Autonomy motivation, controlled motivation, or on the Relative Autonomy Index, which was created by subtracting the controlled motivation score from the autonomous motivation score. The positive Relative Autonomy Index scores indicate that both level 1-3 and level 4 respondents were more controlled motivated than Autonomy motivated.

Table 7. Differences between respondents at education levels $1-3$ vs 4 on the study variables $(N=60)$

\begin{tabular}{lllllll}
\hline Variable & Education Level & $\mathrm{N}$ & Mean & Variance & $\mathrm{t}$ & $\mathrm{p}(2$-tail) \\
\hline Autonomous Motivation & $1-3$ & 35 & 29.7 & 18.9 & .90 & $\mathrm{NS}$ \\
& & & & & & \\
Controlled Motivation & 4 & 25 & 28.9 & 5.9 & & \\
& $1-3$ & 35 & 24.3 & 24.9 & -.28 & $\mathrm{NS}$ \\
Relative Autonomy Index & 4 & 25 & 23.7 & 21.2 & & \\
& $1-3$ & 35 & 5.4 & 38.0 & & \\
& 4 & 25 & 5.2 & 23.3 & .20 & NS \\
\hline
\end{tabular}

Note. 2-sample t-tests, assuming equal variances.

\subsection{Interview Results}

This section presents the Yemeni EFL teachers' views on the impact of the conflict on the student motivation and what can motivate students during the conflict. The first question was "What is the effect of Yemeni conflict on EFL student motivation?" In response to the first question, Yemeni EFL teachers believed that student autonomous motivation has been dramatically affected during the conflict if not totally deteriorated. One interviewee stated:

The students' decrease in motivation for English language learning has become a pervasive phenomenon in our college during the last nine academic years. This fact could be clearly observed in the sort of information students produce in their answers on achievement tests. The products of the students' learning are marked by poor quality and low quantity. 
The interviewees believed that Yemeni EFL students were devoid of any autonomous motivation. They explained that the students are controlled because of the current conflict. One of them states, "All that they want is to read the material at home and memorize it by heart without any understanding." Another pointed out that "As there is no food and security in Yemen and the students suffer along with their families, they decide to study in the hope that it might help them get jobs to help their families."

These responses show that the students are not studying English for the sake of knowledge, but for other factors: to help themselves and their families in the current desperate situation and they are devoid of any autonomous motivation which essentially makes learning exciting and can present great determination and performance.

The responses to the first question support Maslow's 1943 hierarchy of needs that argues one must satisfy his/her physiological and safety needs before trying to meet higher-level needs. Teachers responses also confirm that the students' lack of autonomous motivation is caused by the current Yemeni conflict as nothing else provides interest to the Yemeni EFL students. Another issue is that most EFL teachers have left Yemen to get better jobs overseas, causing what is called "brain drain". This is consistent with two studies (Muthanna, 2015; Muthanna \& Sang, 2018) the findings of which were that the brain drain of the talented Yemeni teachers has certainly weakened the quality of higher education in the country.

The teacher responses to the second question, "What could motivate the Yemeni EFL students during the conflict?" were very pessimistic. Teachers argued that a teacher who is not motivated and who is teaching without being paid his or her salary will never be able to motivate his/her students. Moreover, a student who lacks basic needs cannot be easily motivated. All interviewees expressed that ending the conflict would be the first step toward student motivation. One of the interviewees argued:

It is difficult to believe that it is impossible to motivate students in the absence of current opportunities and without a clear vision of a better future. When teachers are not motivated, they cannot motivate their students. As the Arabic proverb says, "You cannot give what you do not have."

Thus, the interviews with the EFL teachers revealed that it is difficult to increase student autonomous motivation in the current Yemeni context. It is also difficult and illogical to ask teachers to support student autonomous motivation since they have been teaching without being paid for several years. One interviewee maintained that:

Increasing the motivation for learning begins and ends with teachers. If the teacher has a monthly salary that is enough for him to live in a respectable way, he/she can create several strategies and techniques to increase the motivation for teaching and/or learning any subject.

The significance of the teachers' role to motivate the students is consistent with Dörnyei's finding that "Any motivational practice has to begin by motivating the teachers themselves: if a teacher is motivated, his/her class is likely to follow suit" (Dörnyei, 2018, p. 1). It also supports Oga-Baldwin et al. (2017, p. 149), who concluded that " $[\mathrm{t}]$ eachers who provide appropriate support and structure to their foreign language lessons help students to engage, which predicts student motivation at the end of the year."

Two interviewees linked student motivation to dependence on Allah's will. One of them shared that teachers motivate students " ... by reminding them of Allah Who is always there and by reminding them that Allah will not forget them either." These interviewees believed that students in the current Yemeni context could only be motivated by religious beliefs. This is consistent with Badrasawi et al. (2018, p. 589) who studied ways to educate Palestinian and Syrian refugees in Malaysia. They found that " $[\mathrm{m}] \mathrm{ost}$ participants have hope for the future and even those who felt despair took comfort in their religious beliefs, i.e., they overcame their negative feelings by trusting that Allah (S.W.T) will support them in overcoming their hardships."

Another technique was suggested by another teacher, who maintained that he has repeatedly been encouraging students to the following effect: "The conflict is temporary and suffering is always followed by happiness." This technique, to some extent, seems to bring about good results, stimulating students and creating interest and hope for the best. This technique suggests that teaching Yemeni students specific strategies for success might allow them to increase their control over their behaviour and environment.

In sum, Yemeni EFL students in Yemen are different from other EFL students who live in peaceful countries. The researcher suggests that an extra effort should be made to motivate Yemeni EFL students who are studying in conflict-affected areas. EFL teachers, curriculum developers, policymakers with the help of the Saudi-led coalition, the United Nations and other available international and local organizations should provide EFL students and teachers with alternatives to learn and teach safely and efficiently. Future research should be 
conducted to investigate the possibility of teaching via online learning and to find other ways to motivate EFL students who are in conflict-affected areas.

\section{Conclusion}

The results of the student questionnaire and the teachers' interviews show that Yemeni EFL student motivation has been negatively affected during the conflict. The questionnaire shows that $88 \%$ of the students tend to be influenced by controlled motivation and only $12 \%$ of them tend to be more autonomously motivated. It also shows that the students at levels 1 and 2 are more autonomously motivated as compared to those at levels 3 and 4 , an indicator that level 3 and 4 students have lost some of their idealism due to the increasing deterioration of all aspects of life in the country. SDT shows that when the students are more controlled, their outcomes and achievements are less satisfactory. Ryan and Deci (2019, pp. 11-12) believe that introjected controlled motivation can be fragile and "presents risks for well-being." They also state that external controlled motivation is difficult to sustain and has poor maintenance and transfer qualities. It is also believed that autonomous motivation "... presents great persistence, performance and well-being at an activity or within a domain" (Ryan, 2009, p. 2).

The teachers' interviews indicated that the Yemeni EFL students focus on the lower levels of Maslow's hierarchy of needs, that is, the physiological needs (food, water, warmth, rest and shelter) and safety needs (security, freedom from fear, stability and safety), which are not satisfied under the current conditions of the on-going conflict. Maslow (1943) believed that one must satisfy the lower needs before trying to meet the higher-level needs. This can be seen in the report that shows that $75 \%$ of Yemenis are on the brink of famine. The Saudi Gazette in its August 2018 issue states that “... nearly 18 million people do not know where their next meal is coming from and more than 8 million of them live in extreme hunger and depend entirely on external food assistance" (Saudi Gazette, August 2018). This finding is consistent with two studies in China and Japan that found that the students who come from higher-income parents are more likely to be autonomously motivated and self-determined (Butler, 2014; Oga-Baldwin, 2017).

\section{Implications for Future Research}

Based on the findings of the current research, future research should investigate the following issues:

1) There should be similar studies in peaceful areas in Yemen, or anywhere else in the world. They should compare the results of this study which found that $88 \%$ of the students are controlled motivated. It should attempt to find out if the high percentage of controlled motivation is attributed to conflict or it is more common in Yemen than in any other conflict-affected area.

2) The findings of the small minority of the current students (12\%) who are autonomously motivated raise an important question to be investigated for future studies. The study should investigate "What allows the $12 \%$ of the students to maintain an autonomous motivation to study English despite living in very difficult circumstances while the majority is more controlled motivated?" The study should find out the factors that help them to be autonomously motivated and try to translate some of those factors into learning strategies for the other (12\%) students who are influenced by controlled motivation.

3) There should be a future study of the strategies that promote and support EFL students' autonomous motivation among the students who live in areas of conflict.

4) There should be a study to investigate the possibility of teaching EFL students via online learning in conflict-affected zones particularly in areas where schools and universities are in danger.

5) Finally, since the interview showed that religion could motivate students, there should be a future research to investigate the correlation between religious beliefs and autonomous motivation.

\section{References}

Al-Kadasi, A. M. G. (2016). Motivation and demotivation among learners of English in the faculty of education-Arhab in Sana'a University. International Journal of English Language, Literature and Translation studies, 3(4), 321-331.

Al-Quyadi, A. (2000). Psycho-sociological variables in the learning of English in Yemen. Unpublished PhD. Thesis, Bhagalpur University.

Al-Sohbani, Y. A. (1997). Attitudes and motivation of Yemeni secondary school students and English language learning. Unpublished Ph. D. Thesis, Department of English, University of Pune, India.

Al-Sohbani, Y. A. Y. (2015). The role of attitudes and motivation in learning English as a foreign language 
among Yemeni rural secondary school students. Journal of Teaching and Teacher Education, 3(01). https://doi.org/10.12785/jtte/030103

Al-Tamimi, A., \& Shuib, M. (2009). Motivation and attitudes towards learning English: A study of petroleum engineering undergraduates at Hadhramout University of Sciences and Technology. GEMA Online $\mathbb{B}$ Journal of Language Studies, 9(2).

Attamimi, R. A., \& Abdul Rahim, H. A. (2011). Socio-economic orientations in foreign language learning motivation: The case of Yemen. Asian EFL Journal, 13(4), 167-197.

Badrasawi, K. J., Ahmed, I. O., \& Eid, I. M. (2018). Exploring ways to provide education in conflict zones: Implementation and challenges. Intellectual Discourse, 26(2), 567-594.

Black, A. E., \& Deci, E. L. (2000). The effects of instructors' autonomy support and students' autonomous motivation on learning organic chemistry: A self - determination theory perspective. Science Education, 84(6), 740-756. https://doi.org/10.1002/1098-237X(200011)84:6<740::AID-SCE4>3.0.CO;2-3

Boset, S. A. A., Asmawi, A., \& Abedalaziz, N. (2017). The relationship between competency and work motivation of EFL Teachers at Public Secondary Schools in Yemen. Arab World English Journal, 8(4). https://doi.org/10.24093/awej/vol8no4.14

Burns, M., \& Lawrie, J. (2015). Where it's needed most: Quality professional development for all teachers (p. 162). New York, NY: Inter-Agency Network for Education in Emergencies.

Butler, R. (2014). What teachers want to achieve and why it matters: An achievement goal approach to teacher motivation. In Teacher Motivation (pp. 42-57). Routledge.

Chanal, J., \& Guay, F. (2015). Are autonomous and controlled motivations school-subjects-specific? PloS One, 10(8), e0134660. https://doi.org/10.1371/journal.pone.0134660

Chang, K. (2017). Examining learners' self-regulatory behaviors and their task engagement in writing revision. Bulletin of Educational Psychology, 48(3), 449-467.

Deci, E. L., Connell, J. P., \& Ryan, R. M. (1989). Self-determination in a work organization. Journal of Applied Psychology, 74(4), 580. https://doi.org/10.1037/0021-9010.74.4.580

Deci, E., \& Ryan, R. M. (1985). Intrinsic motivation and self-determination in human behavior. Springer Science \& Business Media. https://doi.org/10.1007/978-1-4899-2271-7

Deci, E. L., \& Ryan, R. M. (2002). Overview of self-determination theory: An organismic dialectical perspective. Handbook of Self-determination Research, 3-33.

Deci, E. L., \& Ryan, R. M. (2008). Self-determination theory: A macro theory of human motivation, development, and health. Canadian psychology/Psychologie Canadienne, 49(3), 182. https://doi.org/10.1037/a0012801

Deci, E. L., \& Ryan, R. M. (2012). Motivation, personality, and development within embedded social contexts: An overview of self-determination theory. The Oxford Handbook of Human Motivation, 85-107. https://doi.org/10.1093/oxfordhb/9780195399820.013.0006

Dillon, A., \& Stolk, J. (2012, October). The students are unstable! Cluster analysis of motivation and early implications for educational research and practice (pp. 1-6). In 2012 Frontiers in Education Conference Proceedings. https://doi.org/10.1109/FIE.2012.6462485

Dörnyei, Z. (2018). Motivating students and teachers. The TESOL Encyclopedia of English Language Teaching, 1-6. https://doi.org/10.1002/9781118784235.eelt0128

Feri, R., Soemantri, D., \& Jusuf, A. (2016). The relationship between autonomous motivation and autonomy support in medical students' academic achievement. International Journal of Medical Education, 7, 417. https://doi.org/10.5116/ijme.5843.1097

Kline, R. (2011). Convergence of structural equation modeling and multilevel modeling. In M. Williams \& W. P. Vogt (Eds.), The SAGE handbook of innovation in social research methods (pp. 562-589). London: SAGE Publications Ltd. https://doi.org/10.4135/9781446268261.n31

Maslow, A. H. (1943). A theory of human motivation. Psychological Review, 50(4), 370. https://doi.org/10.4135/9781446268261.n31

Muthanna, A. (2015). Quality education improvement: Yemen and the problem of the 'brain drain.' Policy Futures in Education, 13(1), 141-148. https://doi.org/10.1177/1478210314566734 
Muthanna, A., \& Sang, G. (2018). Brain drain in higher education: Critical voices on teacher education in Yemen. London Review of Education, 16(2), 296-307. https://doi.org/10.18546/LRE.16.2.09

Oga-Baldwin, W. Q. (2015). Supporting the needs of twenty-first century learners: A self-determination theory perspective. In Motivation, Leadership and Curriculum Design (pp. 25-36). Springer, Singapore. https://doi.org/10.1007/978-981-287-230-2_3

Oga-Baldwin, W. Q., Nakata, Y., Parker, P., \& Ryan, R. M. (2017). Motivating young language learners: A longitudinal model of self-determined motivation in elementary school foreign language classes. Contemporary Educational Psychology, 49, 140-150. https://doi.org/10.1016/j.cedpsych.2017.01.010

Rajab, K. D. (2018). The effectiveness and potential of E-learning in war zones: An empirical comparison of face-to-face and online education in Saudi Arabia. IEEE Access, 6, 6783-6794. https://doi.org/10.1109/ACCESS.2018.2800164

Ryan, R. (2009). Self-determination theory and well-being. Social Psychology, 84(822), 848.

Ryan, R. M., \& Connell, J. P. (1989). Perceived locus of causality and internalization: Examining reasons for acting in two domains. Journal of Personality and Social Psychology, 57(5), 749. https://doi.org/10.1037/0022-3514.57.5.749

Ryan, R. M., \& Deci, E. L. (2000). Self-determination theory and the facilitation of intrinsic motivation, social development, and well-being. American Psychologist, 55(1), 68. https://doi.org/10.1037/0003-066X.55.1.68

Ryan, R. M., \& Deci, E. L. (2017). Self-determination theory: Basic psychological needs in motivation, development, and wellness. Guilford Publications. https://doi.org/10.7202/1041847ar

Ryan, R. M., \& Deci, E. L. (2019). Brick by brick: The origins, development, and future of self-determination theory. Advances in Motivation Science, 6, 111-156. https://doi.org/10.1037/0022-3514.65.3.586

Saeed, G. M. (2015). Influence of gender on undergraduate EFL learners' motivation towards learning English: A case study of Thamar University, Yemen. Bangladesh Research Foundation Journal, 4(1), 1-11. Retrieved from http://www.researchfoundbd.org/images/Vol.4-No.1-2015.pdf

Saudi Gazette Newspapers. (2018). Kuwait supports WFP's fight against famine in Yemen (7-August-2018). Retrieved November 11, 2018, from http://saudigazette.com.sa/article/540720/World/Mena/Kuwait-supports-WFPs-fight-against-famine-in-Yem en

Stolk, J. D., Jacobs, J., Girard, C., \& Pudvan, L. (2018, October). Learners' Needs Satisfaction, Classroom Climate, and Situational Motivations: Evaluating Self-Determination Theory in an Engineering Context (pp. 1-5). In 2018 IEEE Frontiers in Education Conference (FIE). IEEE.

https://doi.org/10.1109/FIE.2018.8658880

Tabachnick, B. G., \& Fidell, L. S. (2007). Using multivariate statistics (5th ed.). New York, NY: Allyn and Bacon.

Williams, G. C., \& Deci, E. L. (1996). Internalization of biopsychosocial values by medical students: A test of self-determination theory. Journal of Personality and Social Psychology, 70, 767-779. https://doi.org/10.1037/0022-3514.70.4.767

\section{Copyrights}

Copyright for this article is retained by the author, with first publication rights granted to the journal.

This is an open-access article distributed under the terms and conditions of the Creative Commons Attribution license (http://creativecommons.org/licenses/by/4.0/). 